\title{
Reading Proficiency across Economies: Measuring the Quality of Education and its Effect on Economic Growth
}

\author{
Sudatta Banerjee* \\ (Senior Research Fellow, Jawaharlal Nehru University)
}

\begin{abstract}
:
The paper considers the determinants of reading proficiency of the working population in an economy using data on the per capita circulation of newspapers for forty countries over some years. The results indicate that parents' education and government expenditure on education during schooling are important in developing reading proficiency. Based on this analysis the paper develops a measure of the quality of education of the working population in terms of its impact on the per capita circulation of newspapers. By incorporating this measure in growth regressions it is observed that the quality of education may have a significant effect on the growth of nations.
\end{abstract}

Key words: Education, Human Capital, Schooling Quality, Economic Growth JEL Codes: I20, J24, O40

*I am grateful to my Ph.D. supervisor Dr. Subrata Guha for his guidance regarding my work and to late Professor Sanghamitra Das for her suggestions on econometric analysis during the classes I attended in ISI, New Delhi. I am thankful to late Dr. Manashi Banerji for being a constant support system.

E-mail address: sudattabanerjee@gmail.com 


\section{Introduction}

Viewpoints on determinants of economic growth have changed over the years. The earlier generation of theories, dealing mainly with exogenously driven explanations of long-term growth theories [e.g. Solow (1956)], were criticized by a group of growth theorists, led by Romer (1986), and this led to construction of endogenous growth models. Here, crucial importance is usually given to the production of new technologies and human capital.

It is important to know that physical capital is not the only type of capital. Human capital should be considered as well to determine whether differences in capital are important to differences in income across nations. Human capital consists of the acquired abilities, skills, and knowledge of individual workers.

In the models of Romer (1986), Lucas (1988) and Rebelo (1991), developed on the basis of the works of Arrow (1962), Sheshinski (1967) and Uzawa (1965), growth goes on indefinitely, because the returns to investment in a broad class of capital goods, including human capital, do not necessarily diminish as economies develop. Thus when human capital is included in the definition of capital, the concept of diminishing returns can be relaxed, which leads to long-term growth even in the absence of exogenous technological progress. Hence, the production of human capital may be an alternative to improvements in technology as a mechanism to generate long term growth (Barro and Sala-i-Martin, 1995).

A large number of growth regressions containing human capital variables in the set of regressors have appeared following the early work of Barro and others (Barro, 1991, Barro and Sala-i-Martin, 1995, Barro and Lee, 1996). The most commonly used variables used to represent human capital in these growth regressions were primary or secondary school enrolment rates [see, for example, Barro (1991), Mankiw, Romer and Weil (1992), Barro and Lee (1993), Barro (2000)]. Some other variables were also used to represent human capital like educational attainment at the tertiary education levels (Gemmell, 1996), or general intelligence as measured by IQ tests (Jones and Schneider, 2006). It is seen that in most of these studies, human capital variables affected growth rates of countries significantly.

Thus, these early investigations on determinants of economics growth dealt with various measures of formal schooling activities, for example, enrolment rates or 
average years of educational attainment, as proxies for relevant human capital. But these determinants are proxies of quantity of human capital and not the quality.

Various studies have used different proxies to represent quality of education in country specific or cross country studies. One of the most commonly used measure of quality is academic achievement, that is, test scores in some common examination (Hanushek and Kimko, 2000; Barro and Lee, 2001a).

Hanushek and Kimko (2000) showed that direct measures of labour-force quality from international mathematics and science test scores are highly correlated with economic performance in aggregate data. Growth rates are affected by ideas and invention, which in turn are related to the stock of human capital either through research and development activities or through adoption behavior of technologies and ideas. The mathematical framework dealt by Hanushek and Kimko is as follows:

$$
\begin{aligned}
& g_{i}=X_{i} \beta+\gamma Q L_{i}+\varepsilon_{i} \\
& R_{i}=W_{i} \delta+\eta g_{i}+u_{i} \\
& Q L_{i}=Z_{i} \alpha+R_{i}+v_{i}
\end{aligned}
$$

Growth $\left(g_{i}\right)$ of nation $i$ is determined by labour-force quality $\left(Q L_{i}\right)$ plus a vector of other factors $\left(X_{i}\right)$ [equation (1)]. Growth $\left(g_{i}\right)$ also contributes along with other factors $W_{i}$ to determining the amount of resources devoted to schools and human-capital production (Ri) [equation (2)]. Resources in combination with other inputs $\left(Z_{i}\right)$ determine labour-force quality [equation (3)]

Resources devoted to schools and human-capital production (Ri) included primary-school enrolment rate, average years of schooling, pupil-teacher ratio in primary schools, recurring expenditure on education/GDP, total expenditure on education/GDP, and annual population growth (year 1960 to 1990). Labour-force quality $(Q L)$ included scores of international tests of student achievement in mathematics and science that were conducted from 1960 to 1990 for 31 countries.

The estimates of equation (3) was used to construct an expanded set of labourforce quality measure, $Q L$, which combined observed quality with predicted quality for all countries without observed test data but with data on the right-hand-side measures. So the number of countries was expanded to 78. The estimate of labourforce quality measure, $Q L$, was used as an explanatory variable to determine average annual growth rate in real per capita GDP from equation (1). The other variables used 
were per capita income in 1960, average years of schooling, annual population growth (years 1960 to 1990, number of countries-78).

Since it was impossible to estimate the complete system of equations with the available data, a direct estimation of equation (3), the human capital production function was done. It was assumed that as long as $u$ and $v$ were uncorrelated estimation of equation (3) provided consistent estimates of the production parameters. It was assumed that international level of ability of students did not vary across countries or was exogenous to other determinants considered. This study estimated several variants of equation (3). The results indicate that variation in school resources did not have strong effect on test performance. The education of the parents which was proxied by quantity of schooling of the adult population was significant and positive.

In order to study the differences in growth across countries, the group of countries was expanded by projecting labour force quality based on observed characteristics. Several variants of equation (1) were estimated to get the growth estimates. The measures of labour force quality were statistically significant. A one standard deviation change in quality resulted in a slightly greater than one percentage point difference in annual real growth rates. Thus, it was seen that direct measures of labour-force quality from international mathematics and science test scores are strongly related to growth rates of real per capita GDP in cross country regressions. The result indicates that quality of schooling is an important component of human capital.

Barro and Lee (2001) also investigated the cross country determinants of educational quality as revealed by test scores and some other measures. They had measured the effects on school outcomes which were measured by internationally comparable test scores, repetition rates, and dropout rates from family characteristics and school resources based on a panel data set for a large number of countries from 1964 to 1991. They extended the data set of Hanushek and Kimko (2000) and considered a panel of test scores in the regressions for 58 countries and analyzed the relationship between test scores and measures of school resources (pupil-teacher ratio, expenditure per student, teachers' salary, length of school year) and family inputs (family income, parents' education).

The regression results indicated the importance of family background, which was measured by the income and education of parents. More school resources were 
also positively related to student performance and the strongest results applies to pupil-teacher ratios. Weak but positive effects were also there for average teacher salary and the length of the school term. So the findings were consistent with a view that inputs from schools, families, and communities are important in improving school quality. Also it was seen that per capita GDP was insignificantly related to science and mathematics scores but strongly related to reading scores. So from this study of cross-country data it was seen that differences in schooling quality across countries are considerable and can be explained in part by a set of quantifiable explanatory variables.

But there are some problems with these studies. The test scores which are used are taken from different sources (International Association for the Evaluation of Educational Achievement, International Assessment of Educational Progress, Third International Mathematics and Science Study, International Adult Literacy Survey etc.), which though comparable is based on different curricula and relates to students of different ages. Observations of these surveys apply to different years, and are mostly available for the 1990s. The sample sizes are small. Curriculums of studies are different for different countries and this may affect the performance in the common international tests. These may hamper comparisons across countries. Moreover, the tests are not conducted in all countries. Especially in developing countries the section of the population that appears for these international exams is very small.

Dreze and Sen (2002) point out that if economic growth requires the introduction of more advanced technologies that need to be taught to the workforce, or requires a shift from an agriculture-based to an industry- and services-based economy, then an educated workforce will be necessary for economic growth. A welleducated workforce tends to be more responsive to and absorb faster new ideas and new technology, and in this way the diffusion of knowledge is much faster. Since such human capital or knowledge is transmitted through written materials, reading ability and skills become essential for development. It is known that knowledge of mathematics and science, are reflected in test scores, which is helpful for scientific and technological development of a country. But, the present case considers the reading proficiency of the working population which is the basis of an efficient workforce (able to understand instructions and do their duty well) which is equally needed for development of a country. Also, it is known that reading proficiency is significantly related to growth rates of real per capita GDP [Barro and Lee (2001a)]. 
Thus, it can be assumed that the level of reading proficiency of the working population represents an important dimension of the level of education which is not simply captured by quantity of education as measured by literacy rates, enrolment rates or years of schooling but depends on the quality of education of the workforce.

In this paper, the per capita circulation of newspapers in an economy is taken as the indicator of the level of reading proficiency of the working population.

The per capita circulation of newspapers can be considered as an indicator of reading proficiency of the working population due to several factors. First, since access to and distribution of newspapers is present in almost all countries, major portion of the population of the world can be represented and thus comparison can be done across countries. Moreover, circulation of newspapers can be related to ability and inclination to read. This factor can be related to quality education, since with the help of good quality education, one not only develops the ability but the desire to read. Also it is seen that in majority of studies (Hanushek, 2000, Barro and Lee, 2001a), 'internationally comparable' test scores were used to represent quality. But there are many developing countries for which test scores are not available since those tests are not conducted in all countries. But since circulation of newspapers is present in all countries, developing countries for which test scores are not available can also be considered.

But it is also known that circulation of newspapers is not only determined by quality of education. It is determined by other factors also like present income of the individuals because this represents the purchasing power of the workforce, which decides whether one can purchase the newspaper. Also, the quantity of education affects circulation. This is so because one will buy the newspaper if he/she is able to read it. Thus circulation of newspapers is also affected by factors like literacy and educational attainment of the workforce. Now, circulation will also be affected on how freely newspapers can be printed and distributed in any country. Thus circulation of newspapers will also depend on degree of press freedom prevailing in a country. So, all these factors are also considered in this analysis.

After controlling the effects of these variables, this paper tries to estimate the effects of quality. There are several variables which can influence quality of education. Various studies have been done to find different determinants of quality of human capital. It is seen that pupil's social status and the development level of a country affects achievement of pupils (e.g. Heyneman and Loxley (1983) in a study of 
the effects of primary school quality on academic achievement for 29 countries mainly in Africa, Asia, Latin America and Middle East). Studies show that genetic and socio-economic character of pupils, pupil-specific school inputs, and peer group characteristics affect academic achievement (e.g. in Summers and Wolfe (1977) in a study of 627 sixth-grade elementary school students in 103 elementary schools in Philadelphia School District in 1970-71). A large number of studies have concentrated on the effect of pupil-teacher ratio on academic achievement as measured by test scores or labour market performance (Krueger (1999), Angrist and Lavy (1999), Card and Krueger (1992), Barro and Lee (2001a)). Students performed better in classes with low pupil-teacher ratios.

In the case of India, The National Policy on Education 1986 emphasized the need for periodical achievement surveys at different stages of school education to assess the health of the education system. National Achievement Surveys (NAS) for class V students, conducted by NCERT, found that community participation and a greater number of teachers have maximum impact on the achievement of students.

According to Pan Latin American Kids Study 1998, Audits and Surveys Worldwide, newspaper readership is correlated with the educational level of the head of households and socio-economic level of the households (which proxies availability of books, newspapers and magazines). School resources such as government expenditure on education during schooling period of the present working population, class size during schooling of the present working population and salary of teachers during schooling of the present working population are also determinants of quality education. These factors were also considered by Barro and Lee (2001a) and are considered in this present analysis also.

In this analysis, it is assumed that circulation is determined by demand side factors only. Though the degree of press freedom (the freedom of printing and distribution) might appear to be entirely a supply side factor, it is also true that unless there is press freedom in a country there might be less realization of the possibility of having newspapers or of the need for having newspapers and therefore might imply less demand for them. Also, more importantly, greater press freedom implies a greater variety of newspapers covering a greater spectrum of opinions and therefore might imply a greater demand for newspapers in the aggregate.

The organization of the paper is as follows: Section II discusses the determinants of reading proficiency represented by per capita circulation of 
newspapers including the data, methodology, regression results and findings of the analysis. Section III develops a measure of quality of education of the working population in terms of its impact on the per capita circulation of newspapers. Section IV finds the effects of quality of education on economic growth based on two model specifications. This section includes the data, methodology, regression results and findings of the study. Section V reports the summary and concluding remarks of the study.

The paper finds that parental education of the working population, government expenditure on education during schooling period of the present working population, the present variables - literacy rate and proportion of population who have completed secondary schooling and the time dummies included to capture the trends of circulation of newspapers over time are significant determinants of per capita circulation of newspapers. Pupil-teacher ratio appears to be an important variable in most cross country studies relating to determinants of quality of education, as represented by test scores (e.g. Barro and Lee (2001a)). But this variable turns out to be insignificant in this study. Next, in the study of the relationship between quality of education and economic growth, it is found that there is a significant effect of quality of education as measured by its impact on the reading proficiency of the working population on the rate of growth of nations. Apart from quality, the variables which appear to be important in explaining growth rate of countries are initial GDP, fertility rate, political and macroeconomic stability and investment ratios of countries. It is to be noted that, despite the fact that variables representing the quantity of education are insignificant in the specifications, the quality variable is significant. Moreover, quality is not significant in only one specification where quantity is also insignificant.

\section{Determinants of Reading Proficiency}

This section finds the determinants of reading proficiency, as measured by per capita circulation of newspapers. The subsequent subsections discuss the variables used in the analysis, methodology used and reports the regression results and its interpretation.

\section{A. Description of variables and Estimation Procedure}

In this paper, data on per capita circulation of newspapers is used to consider the impact of variables commonly considered as determinants of the quality of 
education on the level of reading proficiency of the working population. The trends of region-wise circulation of newspapers (for 1000 inhabitants) along with population, over the years 1980 to 2005 is shown in Appendix III. Some present and some past variables are considered to explain per capita circulation of newspapers to a certain extent.

The relationship between circulation of newspapers and the factors determining it is represented with the help of the following specification:

$\operatorname{lncir}_{i t}=\alpha_{i}+\beta_{1}$ litpr $_{i t}+\beta_{2} \operatorname{secpr}_{i t}+\beta_{3} \operatorname{lnpcgdppr}_{i t}+\beta_{4}$ pfpr $_{i t}+\beta_{5}$ ptrp $_{i t}+\beta_{6}$ edup $_{i t}+$ $\beta_{7} \operatorname{lnpchcep}_{i t}+\beta_{8} \operatorname{expp}_{i t}+y_{1}+y_{2}+y_{3}+y_{4}+n_{1}+n_{2}+n_{3}+n_{4}+n_{5}+n_{6}+n_{7}+\varepsilon_{i t} \ldots .$. (i), where, $i$ represents countries and $t$ represents the years.

The present variables considered are literacy rate, proportion of population who has completed secondary schooling, real GDP per capita, and press freedom. The past variables are used to represent some determinants of quality in the education period of the present work force. The past variables taken are pupil teacher ratio, average years of schooling of total population aged 25 years and over, household consumption expenditure per capita and government expenditure on education as percentage of GNP. So, it can be seen that the past variables taken, somewhat represent the factors which determine quality of education of the present work force. Thus, here, the intention is to eliminate the effect of the present explanatory variables to find the importance of the factors influencing quality. The present years considered are 1998, 1995, 1990, 1985 and 1980 and the corresponding years in the past are 1980, 1975, 1970, 1965 and 1960.

The present analysis takes log of circulation of newspapers per 1000 inhabitants (lncir) as the proxy for reading proficiency of the present working population. The data is taken from United Nations Statistical division [original source: UNESCO Institute of Statistics and World Association of Newspapers and Statistical Yearbook- Economic and Social Affairs (Statistics Division)-1997].

The following explanatory variables are considered in the analysis:

i. Ability to Read: Present literacy rate (litpr) is used to represent present quantity of education. This is considered to take care of the fact that one will buy a newspaper when he/she is able to read it. The variable, litpr, represents the literacy rate of the present years considered. The data is taken from UNESCO Institute of Statistics. 
ii. Educational Attainment: Proportion of population who has completed secondary schooling (secpr) is used to represent the educational attainment of the present working population. Demand for newspapers will depend on the educational level of the population. The variable, secpr, represents the proportion of population who has completed secondary schooling. The data is taken from in Barro and Lee (2001b).

iii. $\quad$ Present Income Level: Log of real GDP per capita (lnpcgdppr) is taken to represent the present income of the individual. This factor determines whether an individual is able to buy a newspaper or not. The variable, $\operatorname{lnpcgdppr}$, included represents the log of real GDP per capita for all the present years considered. The data is taken from PENN World Table.

iv. Degree of Press Freedom: Press freedom index ${ }^{1}$ is used to represent the degree of press freedom prevailing in a country. This factor determines freedom of printing and distribution of newspapers in a country. In the present case, the number 0 is assigned for the free press group, 1 for partially free press group, and 2 for the non free press group. The variable here, $p f p r$, represents the press freedom index rankings for all the present years. The data is taken from Freedom House.

v. Class size during schooling of the present work force: Past pupil-teacher ratio (ptrp) is taken as a proxy for class size during schooling of the present working population. It is seen in Barro and Lee (2001a) that pupil-teacher ratio is negatively related with test scores. Thus this study also wants to find whether large class size has negative effects on reading proficiency. The variable, ptrp, included in the analysis represents the pupil-teacher ratio of all the past years considered. The data of pupil-teacher ratio is taken from UNESCO Institute of Statistics and Barro and Lee (2001b).

vi. Parents' education level for the present workforce: Past average years of schooling of total population aged 25 years and over (edup) is taken as a proxy for the education of the parents of the present working population. This variable is taken to account for the possibility that parents with a higher level of education may be more motivated to educate their children and provide them with a suitable home environment for learning. This variable is statistically significant in explaining test scores in Barro and Lee (2001a) and so here also I want to analyze how much variation in reading proficiency in 
explained by education of the parents. The variable, edup, used here represents average years of schooling of total population aged 25 years and over for all the past years. The data is taken from in Barro and Lee (2001b).

vii. Consumption expenditure of the parents of the present work force: Log of household consumption expenditure per capita, past, (lnpchcep), is taken as a proxy for the 'ability to spend' of the parents of the present working population. This variable is important because it is vital to know whether parents were able to provide their children with quality education, whether children got enough nutrition to increase their ability to learn etc. The variable, Inpchcep, used in this case represents the log of household consumption expenditure per capita for all the past years. The data is taken from World Development Indicators 2001 (provided By World Bank).

viii. Government expenditure on education during schooling of the present work force: Government expenditure on education as percentage of GNP, past, (expp) is taken as a proxy for government expenditure during schooling period of the present workforce. In this analysis, I want to know whether government expenditure on education can explain the reading proficiency of the working population. The variable, expp, included in this analysis represents government expenditure on education as percentage of GNP for all the considered past years. The data is taken from UNESCO Institute of Statistics and UNESCO- The Statistical Yearbooks of various years.

$\beta_{i}(i=1,2, \ldots, 8)$ are the fixed coefficients of the explanatory variables (which vary both with country and year) to be estimated. $\alpha_{i}$ is the country-specific effect. Country-specific effects capture the variation of the dependent variable due to the unobservable country-specific characteristics.

This paper takes 35 years to be the average age of the present work force and 15 years to be the age for completion of secondary schooling. Thus, when I take the present variables of a certain year, the values of the past variables for the year 20 years preceding it, is taken. Thus when 1980 is taken as present, 1960 is considered to be the relevant year in the past. However, for 1998 as the present year, 1980 is considered as the relevant year in the past - this has been done because in 2000 the data of circulation of newspaper is unavailable for many countries making the data set too small. The representative age of the working population is taken to be 35 , mainly 
due to constraints in availability of data. Data related to variables like average years of education and expenditure per student are not available for years before 1960.

To perform the statistical analyses and to find out the important variables to explain the present per capita circulation of newspapers or reading proficiency of the present working population, the present study uses the data for the different variables mentioned above from a maximum of 40 countries. The choice of countries has been totally based on the availability of data. Panel data has been used to take care both of the cross-section and the time series element at the same time.

The country sets that have been included here are a good combination of 19 developed and 21 developing countries. Among these 40 countries 19 countries belong to the high income group, 4 countries in the upper middle income group, 12 countries in the lower middle income group and 5 countries in the low income group (World Bank classification, 2007). Thus a heterogeneous groups of countries have been included here which allows for considerable variation in the values of the variables included.

All the exercises that have been done here are based on balanced panel data i.e., all the countries are observed over the entire sample period. Thus total number of observations in each case is equal to the number of countries included multiplied by total number of years considered for each country. There variables which vary both with time and country and there are many variables which are time and country invariant. It becomes difficult to include all of these variables in the analysis and omission of these might lead to biased estimated results. One is able to control for these time-invariant and country-invariant variables by using panel data

This equation can be estimated in several ways by making different assumptions regarding the components of the error term and their correlation with the explanatory variables. A simple way is to ignore the country and time specific fixed effects and use ordinary least square technique. But one cannot ignore the possibility of existence of time-specific and country-specific effects. For this purpose, in this present case, time and regional dummies are included in the regression analysis and least square dummy variable method is used for estimation purpose.

Time dummies representing 1980, 1985, 1990, 1995 and 1998 are considered. For the present analysis, 1998 is taken as control group and thus $y_{1}, y_{2}, \mathrm{y}_{3}$ and $y_{2}$ are included in the regression. 
Again, in this case, regional dummies are included instead of country dummies. This is done because, in this analysis, the number of countries included (40) is large compared to the number of years considered. Thus inclusion of 39 country dummies can lead to biased estimated results. Since there is already presence of much multicollinearity in this case, country dummies are not used to prevent more increase in multicollinearity. Thus, the forty countries are divided in 8 regions and 7 regional dummies are used in the analysis. This is done according to UN classification. (Regions are given in Appendix I)

Since, there is presence of both autocorrelation and heteroscedasticity in this case, the standard errors have been clustered for the present purpose. The variance inflation factor (VIF) was also checked. Though the mean VIF for the main regression is about 7.6, the VIF of some variables are quite high, indicating the presence of multicollinearity. These variables are retained in the regression for theoretical purposes, i.e. the model can be rightly specified in this case.

\section{B. Regression Results and Interpretation}

In Table1, the regression results are reported. Certain variables in the regression are also dropped and added to see the variation in the results.

In Table 1, column I, it is seen that among the present variables, litpr and secpr are statistically significant, which indicates their importance in determining circulation of newspapers. It is obvious that one should be able to read and educated in order to demand the newspaper.

Among the past variables, it is seen that average years of education (edup) is highly statistically significant with the correct sign. Thus, it can be said that parents' education has a significant effect on the reading proficiency of the workforce.

It is also seen that past government educational expenditure as percent of GNP (expp) is positively significant. So government's initiative to impart education, to provide educational facilities and develop educational infrastructure is important for increasing reading proficiency of the workforce. Even if private initiative is important, if it is backed up by government's initiative, the effect is increased.

So these variables are important in explaining reading proficiency of the workforce. Past pupil-teacher ratio turns out to be statistically insignificant. 
Table 1: Panel Regression for circulation of newspapers

\begin{tabular}{|c|c|c|c|}
\hline \multirow[t]{2}{*}{$\begin{array}{l}\text { Independent } \\
\text { Variables }\end{array}$} & \multicolumn{3}{|c|}{$\begin{array}{l}\text { Dependent Variables: Log of circulation of } \\
\text { newspapers per } 1000 \text { inhabitants }\end{array}$} \\
\hline & $I$ & II & III \\
\hline Present Literacy Rate & $\begin{array}{l}0.023 \\
(0.011,0.048)\end{array}$ & $\begin{array}{l}0.022 \\
(0.010,0.040)\end{array}$ & $\begin{array}{l}0.025 \\
(0.010,0.018)\end{array}$ \\
\hline $\begin{array}{l}\text { Proportion of population } \\
\text { completed secondary } \\
\text { schooling }\end{array}$ & $\begin{array}{l}0.012 \\
(0.006,0.036)\end{array}$ & $\begin{array}{l}0.012 \\
(0.006,0.034)\end{array}$ & $\begin{array}{l}0.012 \\
(0.006,0.033)\end{array}$ \\
\hline $\begin{array}{l}\text { Log of Present per capita } \\
\text { GDP }\end{array}$ & $\begin{array}{l}0.224 \\
(0.338,0.512)\end{array}$ & $\begin{array}{l}0.287 \\
(0.195,0.149)\end{array}$ & \\
\hline Press Freedom & $\begin{array}{l}-0.101 \\
(0.125,0.427)\end{array}$ & $\begin{array}{l}-0.112 \\
(0.110,0.314)\end{array}$ & $\begin{array}{l}-0.077 \\
(0.123,0.535)\end{array}$ \\
\hline $\begin{array}{l}\text { Past Average Years of } \\
\text { Education }\end{array}$ & $\begin{array}{l}0.140 \\
(0.065,0.039)\end{array}$ & $\begin{array}{l}0.146 \\
(0.049,0.005)\end{array}$ & $\begin{array}{l}0.132 \\
(0.061,0.037)\end{array}$ \\
\hline Past Pupil-Teacher Ratio & $\begin{array}{l}-0.005 \\
(0.010,0.640)\end{array}$ & $\begin{array}{l}-0.006 \\
(0.012,0.644)\end{array}$ & $\begin{array}{l}-0.003 \\
(0.012,0.811)\end{array}$ \\
\hline $\begin{array}{l}\text { Log of Past per capita } \\
\text { Household Consumption } \\
\text { Expenditure }\end{array}$ & $\begin{array}{l}0.056 \\
(0.214,0.794)\end{array}$ & & $\begin{array}{l}0.174 \\
(0.127,0.177)\end{array}$ \\
\hline $\begin{array}{l}\text { Past Govt. Educational } \\
\text { Expenditure as percent of } \\
\text { GNP }\end{array}$ & $\begin{array}{l}0.103 \\
(0.029,0.001)\end{array}$ & $\begin{array}{l}0.102 \\
(0.028,0.001)\end{array}$ & $\begin{array}{l}0.106 \\
(0.028,0.000)\end{array}$ \\
\hline $\mathrm{n}_{1}$ & $\begin{array}{l}1.607 \\
(0.244,0.000)\end{array}$ & $\begin{array}{l}1.620 \\
(0.226,0.000)\end{array}$ & $\begin{array}{l}1.553 \\
(0.222,0.000)\end{array}$ \\
\hline $\mathrm{n}_{2}$ & $\begin{array}{l}0.782 \\
(0.206,0.000)\end{array}$ & $\begin{array}{l}0.804 \\
(0.151,0.000)\end{array}$ & $\begin{array}{l}0.732 \\
(0.168,0.000)\end{array}$ \\
\hline $\mathrm{n}_{3}$ & $\begin{array}{l}0.911 \\
(0.278,0.002)\end{array}$ & $\begin{array}{l}0.946 \\
(0.243,0.000)\end{array}$ & $\begin{array}{l}0.763 \\
(0.223,0.001)\end{array}$ \\
\hline $\mathrm{n}_{4}$ & $\begin{array}{l}1.569 \\
(0.523,0.005)\end{array}$ & $\begin{array}{l}1.578 \\
(0.521,0.004)\end{array}$ & $\begin{array}{l}1.493 \\
(0.517,0.006)\end{array}$ \\
\hline $\mathrm{n}_{5}$ & $\begin{array}{l}1.050 \\
(0.796,0.180)\end{array}$ & $\begin{array}{l}1.032 \\
(0.763,0.184)\end{array}$ & $\begin{array}{l}0.948 \\
(0.779,0.231)\end{array}$ \\
\hline$n_{6}$ & $\begin{array}{l}0.035 \\
(0.537,0.948)\end{array}$ & $\begin{array}{l}0.089 \\
(0.541,0.870)\end{array}$ & $\begin{array}{l}-0.234 \\
(0.554,0.675)\end{array}$ \\
\hline $\mathrm{n}_{7}$ & $\begin{array}{l}0.512 \\
(0.117,0.000)\end{array}$ & $\begin{array}{l}0.519 \\
(0.126,0.000)\end{array}$ & $\begin{array}{l}0.478 \\
(0.114,0.000)\end{array}$ \\
\hline $\mathrm{y}_{1}$ & $\begin{array}{l}0.881 \\
(0.163,0.000)\end{array}$ & $\begin{array}{l}0.878 \\
(0.156,0.000)\end{array}$ & $\begin{array}{l}0.877 \\
(0.168,0.000)\end{array}$ \\
\hline $\mathrm{y}_{2}$ & $\begin{array}{l}0.780 \\
(0.130,0.000)\end{array}$ & $\begin{array}{l}0.780 \\
(0.130,0.000)\end{array}$ & $\begin{array}{l}0.772 \\
(0.135,0.000)\end{array}$ \\
\hline $\mathrm{y}_{3}$ & $\begin{array}{l}0.606 \\
(0.102,0.000)\end{array}$ & $\begin{array}{l}0.605 \\
(0.101,0.000)\end{array}$ & $\begin{array}{l}0.604 \\
(0.105,0.000)\end{array}$ \\
\hline $\mathrm{y}_{4}$ & $\begin{array}{l}0.304 \\
(0.085,0.001)\end{array}$ & $\begin{array}{l}0.306 \\
(0.086,0.001)\end{array}$ & $\begin{array}{l}0.296 \\
(0.088,0.002)\end{array}$ \\
\hline Constant & $\begin{array}{l}-2.335 \\
(2.147,0.283)\end{array}$ & $\begin{array}{l}-2.447 \\
(2.005,0.230)\end{array}$ & $\begin{array}{l}-1.356 \\
(1.371,0.329)\end{array}$ \\
\hline No. of Observations & 200 & 200 & 200 \\
\hline $\mathrm{R}^{2}$ & 0.9045 & 0.9044 & 0.9038 \\
\hline
\end{tabular}

NOTE: The observations in the parentheses represent robust standard errors and p-values respectively. 
There are some past and some present variables included in the equation, which are highly correlated which results in multicollinearity, but these variables are not dropped from the equation to avoid specification bias.

Present real per capita GDP and past per capita household consumption expenditure were dropped from the regression (Column II and III) to see whether dropping of one turns the other variable significant. But they turned out to be insignificant. So, these variables cannot be termed as important in determining circulation of newspapers.

The year dummies are highly positively significant, with a decrease in value of the coefficients over the years (as seen in Table 1), indicating a fall in the circulation of newspapers over the years. This may be due the introduction and development of other media of information over the years like television, internet etc. The regional trends in circulation of newspapers can be seen in Appendix III.

So, it can be said that the level of reading proficiency of the workforce depends to a certain extent on variables influencing the quality of education of the workforce.

\section{Measure of Reading Proficiency}

On the basis of the previous regression (Table1, Column I), this paper now estimates a measure of the quality of education. The past variables included in the regression, capturing the impact of quality of education on per capita circulation of newspapers, are average years of education, pupil-teacher ratio, government spending on education as percent of GNP and household consumption expenditure. Since these four variables are jointly significant, these are used to determine a measure of quality of education in terms of its effect on reading proficiency (as measured by the per capita circulation of newspapers).

Therefore, in equation ( $i$ ), it is assumed that the effects of other variables, other than the quality variables, on circulation of newspapers are absent and so the coefficients of these variables are replaced with zeroes. Thus, the equation, which is used to estimate quality of education, is as follows:

Quality $=-2.335-0.005$ ptrp +0.103 expp +0.56 lnpchcep +0.14 edup

With this equation, a measure of quality of education is estimated for all the 40 countries, considered so far, and now this variable will be used to determine 
whether quality of education has any effect on growth rate of economies. The trends of this estimated quality measure for different regions over the years 1980 to 2005 is given in Appendix IV.

\section{Reading Proficiency and Growth}

Finding the determinants of long-term economic growth has been given much importance since late 1980's. Here, crucial importance is usually given to the production of new technologies and human capital. All recent studies focusing on the determinants of long-term economic growth generally include a proxy for quantity of human capital.

The purpose of our exercise in this section is to check whether quality of education as measured by its impact on reading proficiency of the working population has an effect on the economic growth of nations, independent of the effect of the quantity of education as measured by variables like literacy rates and years of schooling. In order to do this, two growth regression exercises in the literature which found significant effects of human capital (as measured by the quantity of education) on economic growth (Barro, 1992 and 2003) are considered.

Accordingly, in this section, two model specifications derived from these two growth regressions are considered to study the empirical determinants of growth. Since, here, the area of interest is quality of education, our measure of quality of education is included in both the settings, to see whether this variable is important in explaining economic growth.

MODEL I: In the first case, an empirical framework is used to find the determinants of real per capita growth rate including most of the variables used in Barro (1992). In this framework, the measure of quality of education is also included. The variables include initial level of state variables that is stocks of physical capital and human capital. Initial level of per capita GDP enters the model to represent initial stock of physical capital and average years of school attainment represents human capital. Influences of these two variables on economic growth are different. A higher value of human capital raises growth rate, for a given value of physical capital. Initial levels of per capita GDP have a negative effect on growth rate of per capita GDP, indicating convergence (Barro, 2003). Policy variables and national characteristics such as ratio of government consumption to GDP, ratio of domestic investment to 
GDP, distortions due to tariffs, fertility rate, measure of political stability and distortions due to foreign trade are also included in the model.

All the variables as used in Barro (1992), are used here for explaining growth rate of countries. In this specification, our quality measure is also included. The set of countries considered in this paper are different from those used in Barro (1992). Mostly, all the variables turns out to be significant including the quantity of education (average years of school attainment) in Barro (1992).

The next subsections discuss the variables used, estimation procedure and regression results.

\section{A. Description of variables and Estimation Procedure}

The relationship between growth rate of countries and the factors determining it is represented with the help of the following specification:

$$
\begin{aligned}
& \text { growth }_{i t}=\alpha_{i}+\beta_{1} \log (\text { initialGDP })_{i t}+\beta_{2} \log (\text { School })_{i t}+\beta_{3}(\text { Govt-Con })_{i t}+\beta_{4} \\
& \text { [openness } * \log (1+\text { tariff rate })]_{i t}+\beta_{5} \log (1+\text { Black-Markrt Premium })_{i t}+\beta_{6} \text { rev }_{i t}+\beta_{7} \\
& (\text { Invt })_{i t}+\beta_{8}(\text { Fert })_{i t}+\beta_{9}(\text { Quality })_{i t}+y_{1}+y_{2}+y_{3}+y_{4}+n_{1}+n_{2}+n_{3}+n_{4}+n_{5}+n_{6}+n_{7} \\
& +\varepsilon_{i t}
\end{aligned}
$$

where, $i$ represents countries $(i=1,2, \ldots ., 34)$ and $t$ represents the five year periods $(t=$ 1980-85, 1985-90, 1990-95, 1995-2000 and 2000-05).

In this exercise, growth rates of real GDP per capita (growth) are used to represent growth rate of economies. The data on real GDP per capita is taken from PENN World table and growth rates are calculated from this data ${ }^{2}$. The estimation is done for a set of 34 countries (chosen solely on the basis of availability of data) over five-year periods from 1980 to 2005. All exercises are based on a balanced panel. Both year $\left(y_{1}, y_{2}, y_{3}, y_{4}\right)$ and regional dummies $\left(n_{1}\right.$ to $\left.n_{7}\right)$ are included in this case to account for time-specific and country-specific effects and the estimation is done by least square dummy variable method and the standard errors have been clustered to correct for heteroscedasticity and autocorrelation. $\beta_{i}(i=1,2, \ldots, 9)$ are the fixed coefficients of the explanatory variables (which vary both with country and year) to be estimated. $\alpha_{i}$ is the country-specific effect.

The independent variables include:

i. Logarithm of real per capita GDP at the start of each period: This variable represents the initial stock of physical capital. The coefficient of log of real per capita GDP thus represents the rate of convergence. The variable log(Initial 
$G D P$ ) included in the regression represents the log of real per capita GDP for 1980 for the time interval 1980-85, for 1985 for the time interval 1985-90 and so on. The data is taken from PENN World table.

ii. Educational Attainment: It is proxied by average years of school attainment for each period. This variable represents the quantity of education. The variable $\log ($ School $)$ used in the regression is the log of 1 plus the average number of years of educational attainment for the population aged 25 years and over at the start of each 5-year period. The value one in this case represents effective years obtained without formal schooling (Barro, 1992). The data is taken from Barro and Lee (2001b).

iii. Government Consumption: The ratio of government consumption to GDP measures public outlays that do not increase productivity directly. The variable Govt-Con, used in the analysis is the period average of the ratio of real government consumption, exclusive of education and defense, to real GDP. The data on is taken from PENN World Table, Stockholm International Peace Research Institute and UNESCO Institute of Statistics.

iv. Openness and Tariff Rate ${ }^{3}$ : Openness measures natural openness based on area and distance measures and this is constant for each country. Tariff rate is the average official tariff rates on capital imports and intermediaries, weighted by share in imports. The variable included in the analysis is [openness $* \log (1+$ tariff rate $)]$ and this measures the distortions due to tariffs. The data is taken from Barro and Lee (1994), UNCTAD and UN: Statistical Yearbook for various years.

v. Black Market Premium: It is the period average of the black market premium on foreign exchange. This proxies distortion in foreign trade. This variable also proxies macroeconomic instability. The variable used in the regression is Log $(1+$ Black-Markrt Premium). The data is taken from Banks’ Cross-National Time Series Data Archive.

vi. Frequency of Revolutions and Coups: The variable rev represents the number of revolutions and coups per year, averaged over the full sample, 1980-2005. This proxies political instability. The data is taken from Banks' CrossNational Time Series Data Archive. 
vii. Investment Ratio: The variable Invt represents the ratio of real gross domestic investment to real GDP, averaged over each period. The data on is taken from PENN World Table.

viii. Fertility Rate: The variable Fert represents the total fertility rate, averaged over each period. The data is taken from World Bank's comprehensive database of Health, Nutrition and Population (HNP) statistics.

Solow's neoclassical growth model considers investment rate and fertility rate to be exogenous. They do not influence the long run growth rate but have an impact on the growth rate in transition to steady state and the steady state level of per capita output (Barro, 1992). Fertility rate has an influence over population and thus steady state level of output is affected. Investment ratio is used to measure the impact of savings in neoclassical growth models and thus is expected to influence growth rates positively.

ix. Quality of Education: The measure of quality of education (quality) as discussed in Section III is also included.

The five year dummies considered in the analysis represent the periods 198085, 1985-90, 1990-95, 1995-2000, and 2000-05. The first four year dummies are included in the regression and the year dummy for 2000-05 is taken as the control group. The regional dummies for the regions Sub-Saharan Africa and East Asia and Pacific are used to take into account the effect of slow growing and fast growing economies respectively.

\section{B. Regression Results and Interpretation}

Table 2 gives us the regression results for the growth rate of real per capita GDP. This regression includes 34 countries for the periods 1980-85, 1985-90, 199095, 1995-2000 and 2000-05.

Column IV of Table 2 reports the regression using the same variables as used in Barro (1992). Here, it is seen that $\log$ (initial GDP), Rev, Fert, Log(1+Black-Markrt Premium) appear to be statistically significant in explaining growth rate of countries. In our sample of countries, $\log ($ School) turns out to be statistically insignificant.

Next, all the variables as used in Barro(1992) are included in the specification along with the quality of education variable (quality). Column I of Table 2 shows the results in this case. It is seen that $\log ($ initial $G D P)$ affects growth rate significantly. The coefficient -0.019 proves the presence of conditional convergence and the rate of 
Table 2: Panel Regression for Growth Rate of Real Per Capita GDP, 5-Year Intervals from 1980 to 2005

\begin{tabular}{|c|c|c|c|c|}
\hline \multirow[t]{2}{*}{$\begin{array}{l}\text { Independent } \\
\text { Variables }\end{array}$} & \multicolumn{4}{|c|}{$\begin{array}{l}\text { Dependent Variables: Growth Rate of Real Per-Capita } \\
\text { GDP, 5-Year Intervals from } 1980 \text { to } 2005\end{array}$} \\
\hline & $I$ & II & III & $I V$ \\
\hline Log(Initial GDP) & $\begin{array}{l}-0.019 \\
(0.005,0.000)\end{array}$ & $\begin{array}{l}-0.019 \\
(0.005,0.000)\end{array}$ & $\begin{array}{l}-0.023 \\
(0.005,0.000)\end{array}$ & $\begin{array}{l}-0.016 \\
(0.005,0.003)\end{array}$ \\
\hline Log(School) & $\begin{array}{l}-0.019 \\
(0.012,0.114)\end{array}$ & $\begin{array}{l}-0.014 \\
(0.011,0.185)\end{array}$ & $\begin{array}{l}-0.016 \\
(0.011,0.161)\end{array}$ & $\begin{array}{l}-0.006 \\
(0.006,0.326)\end{array}$ \\
\hline $\begin{array}{l}\text { Govt. consumption ratio } \\
\text { (Govt-Con) }\end{array}$ & $\begin{array}{l}0.000 \\
(0.000,0.839)\end{array}$ & $\begin{array}{l}-0.000 \\
(0.000,0.873)\end{array}$ & $\begin{array}{l}-0.000 \\
(0.000,0.409)\end{array}$ & $\begin{array}{l}0.000 \\
(0.000,0.802)\end{array}$ \\
\hline $\begin{array}{l}\text { Openness* } \log (1+\text { Tariff } \\
\text { Rate })\end{array}$ & $\begin{array}{l}-0.006 \\
(0.009,0.540)\end{array}$ & $\begin{array}{l}-0.010 \\
(0.008,0.233)\end{array}$ & $\begin{array}{l}-0.014 \\
(0.009,0.156)\end{array}$ & $\begin{array}{l}-0.003 \\
(0.010,0.769)\end{array}$ \\
\hline $\begin{array}{l}\text { Frequency of Revolutions } \\
\text { and Coups (rev) }\end{array}$ & $\begin{array}{l}-0.028 \\
(0.016,0.081)\end{array}$ & -0.025 (0.015, .117) & $\begin{array}{l}-0.022 \\
(0.016,0.183)\end{array}$ & $\begin{array}{l}-0.030 \\
(0.016,0.064)\end{array}$ \\
\hline Investment ratio (Invt) & $\begin{array}{l}0.001 \\
(0.000,0.104)\end{array}$ & $\begin{array}{l}0.001 \\
(0.001,0.159)\end{array}$ & $\begin{array}{l}0.001 \\
(0.001,0.253)\end{array}$ & $\begin{array}{l}0.001 \\
(0.000,0.101)\end{array}$ \\
\hline Fertility (Fert) & $\begin{array}{l}-0.008 \\
(0.002,0.002)\end{array}$ & $\begin{array}{l}-0.007 \\
(0.002,0.002)\end{array}$ & $\begin{array}{l}-0.005 \\
(0.002,0.054)\end{array}$ & $\begin{array}{l}-0.007 \\
(0.002,0.003)\end{array}$ \\
\hline $\begin{array}{l}\text { Log(1+Black-Markrt } \\
\text { Premium) }\end{array}$ & $\begin{array}{l}-0.002 \\
(0.001,0.001)\end{array}$ & $\begin{array}{l}-0.001 \\
(0.001,0.048)\end{array}$ & $\begin{array}{l}-0.001 \\
(0.001,0.132)\end{array}$ & $\begin{array}{l}-0.002 \\
(0.001,0.000)\end{array}$ \\
\hline Quality & $\begin{array}{l}0.012 \\
(0.006,0.058)\end{array}$ & $\begin{array}{l}0.010 \\
(0.005,0.076)\end{array}$ & $\begin{array}{l}0.010 \\
(0.005,0.042)\end{array}$ & \\
\hline $\mathrm{n}_{1}$ & $\begin{array}{l}-0.000 \\
(0.008,0.974)\end{array}$ & $\begin{array}{l}-0.002 \\
(0.008,0.815)\end{array}$ & $\begin{array}{l}-0.005 \\
(0.008,0.558)\end{array}$ & $\begin{array}{l}-0.002 \\
(0.008,0.788)\end{array}$ \\
\hline $\mathrm{n}_{2}$ & & & $\begin{array}{l}0.002 \\
(0.005,0.714)\end{array}$ & \\
\hline $\mathrm{n}_{3}$ & & $\begin{array}{l}-0.009 \\
(0.004,0.043)\end{array}$ & $\begin{array}{l}-0.018 \\
(0.007,0.018)\end{array}$ & \\
\hline $\mathrm{n}_{4}$ & & & $\begin{array}{l}-0.017 \\
(0.007,0.034)\end{array}$ & \\
\hline $\mathrm{n}_{5}$ & & & $\begin{array}{l}-0.009 \\
(0.008,0.278)\end{array}$ & \\
\hline $\mathrm{n}_{6}$ & $\begin{array}{l}-0.016 \\
(0.010,0.105)\end{array}$ & $\begin{array}{l}-0.024 \\
(0.008,0.008)\end{array}$ & $\begin{array}{l}-0.042 \\
(0.010,0.000)\end{array}$ & $\begin{array}{l}-0.013 \\
(0.011,0.233)\end{array}$ \\
\hline $\mathrm{n}_{7}$ & & & $\begin{array}{l}-0.004 \\
(0.004,0.250)\end{array}$ & \\
\hline $\mathrm{y}_{1}$ & $\begin{array}{l}0.000 \\
(0.004,0.909)\end{array}$ & $\begin{array}{l}0.000 \\
(0.004,0.963)\end{array}$ & $\begin{array}{l}-0.002 \\
(0.004,0.519)\end{array}$ & $\begin{array}{l}-0.001 \\
(0.004,0.724)\end{array}$ \\
\hline $\mathrm{y}_{2}$ & $\begin{array}{l}0.007 \\
(0.004,0.126)\end{array}$ & $\begin{array}{l}0.007 \\
(0.004,0.123)\end{array}$ & $\begin{array}{l}0.005 \\
(0.004,0.278)\end{array}$ & $\begin{array}{l}0.005 \\
(0.004,0.225)\end{array}$ \\
\hline $\mathrm{y}_{3}$ & $\begin{array}{l}0.004 \\
(0.004,0.389)\end{array}$ & $\begin{array}{l}0.004 \\
(0.004,0.347)\end{array}$ & $\begin{array}{l}0.003 \\
(0.005,0.495)\end{array}$ & $\begin{array}{l}0.002 \\
(0.004,0.594)\end{array}$ \\
\hline $\mathrm{y}_{4}$ & $\begin{array}{l}0.007 \\
(0.005,0.115)\end{array}$ & $\begin{array}{l}0.008 \\
(0.005,0.105)\end{array}$ & $\begin{array}{l}0.008 \\
(0.005,0.118)\end{array}$ & $\begin{array}{l}0.007 \\
(0.005,0.165)\end{array}$ \\
\hline Constant & $\begin{array}{l}0.260 \\
(0.053,0.000)\end{array}$ & $\begin{array}{l}0.252 \\
(0.051,0.000)\end{array}$ & $\begin{array}{l}0.289 \\
(0.046,0.000)\end{array}$ & $\begin{array}{l}0.197 \\
(0.039,0.000)\end{array}$ \\
\hline No. of Observations & 170 & 170 & 170 & 170 \\
\hline $\mathrm{R}^{2}$ & 0.3269 & 0.3395 & 0.3534 & 0.3153 \\
\hline
\end{tabular}

NOTE: The observations in the parentheses represent robust standard errors and p-values respectively. 
convergence is about 1.9 percent per year, when other independent variables remain unchanged with change in GDP.

Fert is seen to be negatively significant. Thus it may be said that increase in fertility rate, which in turn increase population, influences growth rate negatively.

Log $(1+$ Black-Markrt Premium) also turns out to be negatively significant indicating that distortions in foreign trade and macroeconomic instability affect growth rate harshly. Frequency of Revolutions and Coups (rev) is also negatively significant at the margin and thus it can be said that political instability also has a negative effect on growth rate.

Most importantly, the new variable included in the model, quality, representing quality of education (reading proficiency) turns out to be positively significant at $6 \%$ level of significance, showing that quality of education has a reasonable impact on growth rate of economies. The inclusion of this new variable does not affect the significance of variables which were already significant in absence of quality. This indicates that quality of education should be improved to have a positive impact on growth rates.

In Column II of Table 2, the dummy for another slow growing region Latin America and the Caribbean $\left(n_{3}\right)$ is included. The results are similar as in Column I, only rev remains no longer significant. Quality still remains weakly significant. But in this case the regional dummies for Latin America and the Caribbean $\left(n_{3}\right)$ and Sub Saharan Africa $\left(n_{6}\right)$ turn out to be negatively significant. The negative significance of these variables shows that the growth consequence of these regions is predicted by the explanatory variables.

In Column III of Table 2, all the regional dummies except for the region North America (control group) are included. Here, $\log ($ initial GDP), Fertility rate, and the regional dummies for Latin America and the Caribbean and Sub Saharan Africa $\left(n_{3}\right.$ and $n_{6}$ ) turn out to be negatively significant. Rev and Log(1+Black-Markrt Premium) remain no longer significant. Quality turns out to be statistically significant in this case.

Thus it can be said that $\log ($ initial GDP), Fertility rate and Quality emerge as important variables in explaining growth rate of countries. The average years of school attainment is insignificant in all the cases, even when the variable quality is absent, indicating, quantity of human capital is not important when considered alone. It should include quality as well. 
MODEL II: In this framework also, the present study finds the determinants of growth (per capita GDP) using most of the variables used in Barro (2003). In this framework, our quality measure is also included. Here also, initial level of per capita GDP is used to represent stock of physical capital. In this case, health is also included in human capital. Thus, average years of school attainment and life expectancy at birth are used. As in Model I, government consumption to GDP, ratio of domestic investment to GDP, fertility rate, and a measure of political stability are included. Here, in this model, the extent of international openness, degree of democracy and inflation rate are also included.

The set of countries considered in this paper are different from those used in Barro (2003). Most of the variables as used in Barro (2003) are used making some alterations. In this paper, life expectancy at birth is used instead of life expectancy at age 1. Also, the subjective measure provided by International Country Risk Guide to analyze the effect of political stability on growth is not considered. To analyze this, the weighted Conflict Index provided by Banks' Cross-National Time Series Data Archive is considered. Mostly, all the variables turn out to be statistically significant including the quantity of education (average years of male secondary and higher schooling) in Barro (2003).

The next subsections discuss the variables used, estimation procedure and regression results.

\section{A. Description of variables and Estimation Procedure}

The relationship between growth rate of countries and the factors determining it is represented with the help of the following specification:

growth $_{i t}=\alpha_{i}+\beta_{1} \log (\text { initialGDP })_{i t}+\beta_{2}(\text { male-schooling })_{i t}+\beta_{3}[1 /($ life expectancy at birth $)]_{i t}+\beta_{4} \log (\text { Fert })_{i t}+\beta_{5}(\text { Govt-Con })_{i t}+\beta_{6}(\text { Conflict Index })_{i t}+\beta_{7}(\text { Democracy })_{i t}+$ $\beta_{8}(\text { Democracy Squared })_{i t}+\beta_{9}(\text { Openness Ratio })_{i t}+\beta_{10}(\text { terms of trade })_{i t}+\beta_{11}(\text { Invt })_{i t}+$ $\beta_{12}(\operatorname{Inf})_{i t}+\beta_{13}\left(\right.$ Quality $_{i t}+y_{1}+y_{2}+y_{3}+y_{4}+n_{1}+n_{2}+n_{3}+n_{4}+n_{5}+n_{6}+n_{7}+\varepsilon_{i t}$

where, $i$ represents countries $(i=1,2, \ldots ., 40)$ and $t$ represents the five year periods $(t=$ 1980-85, 1985-90, 1990-95, 1995-2000 and 2000-05).

Here also, growth rates of real GDP per capita (growth) are used to represent growth rate of economies but the estimation is done for a set of 40 countries (chosen solely on the basis of availability of data) over five-year periods from 1980 to 2005. 
Estimation is done similarly as in Model I. $\beta_{i}(i=1,2, \ldots, 13)$ are the fixed coefficients of the explanatory variables (which vary both with country and year) to be estimated. $\alpha_{i}$ is the country-specific effect.

The independent variables which are also included in Model I are:

i. Logarithm of real per capita GDP at the start of each period [ $\log ($ initialGDP)]

ii. Government Consumption (Govt-Con)

iii. Investment Ratio (Invt)

iv. Fertility Rate $(\log ($ Fert $)$; but in this case the variable included in the regression is log of fertility rate)

v. Quality of Education (Quality)

The data source and the time period for each of the above variables are the same as in Model I.

The new variables included here are:

i. Educational Attainment: According to Barro (2003), the educational attainment variable that is significantly related to growth is average years of male secondary and higher schooling. So here, this variable averaged over each period, is included, and is denoted by male-schooling in the regression. The data is taken from Barro and Lee (2001b).

ii. Life Expectancy: Health is represented by reciprocal of life expectancy at birth. This gives probability of dying per year, if the probability is assumed to be independent of age (Barro, 2003). The variable $1 /($ life expectancy at birth) relates to starting years of each period. The data is taken from UNData.

iii. Conflict Index: Political stability gives more incentives for investment and growth. To capture this, the weighted conflict index from Banks' CrossNational Time Series Data Archive is included. The index considers number of assassinations, general strikes, guerrilla warfare, government crises, purges, riots, revolutions and anti-government demonstrations. The variable conflict index included in the analysis is the average for each period.

iv. Democracy ${ }^{4}$ : This paper includes a measure of democracy in terms of assessment of global political rights and civil liberties. The data for the variable democracy is taken from Freedom house. Ranks are assigned to countries depending on freedom based on political rights and civil liberties. A rank of zero implies the country is totally free, a rank of one as partially free and a rank of two as not free. The scores given by Freedom House are 
averaged over each period and ranks are given to each for each period on the basis of the average scores. A square of this term (democracy squared) is also included in this analysis to allow for a non-linear effect on economic growth.

v. Openness ratio: Openness measure relates to exports plus imports divided by GDP. Since trade openness may be important for a country's growth, this variable is taken in account. Now, openness varies due to country size because larger countries have large internal markets which can be a substitute for international trade, and thus they become less open (Barro, 2003). The variable openness ratio, used here, filters out the relationship between openness and logs of population and area, and thus the variable used shows the effects of government policies on international trade. The data is taken from PENN World Table, and the data included is the average over each period.

vi. Change in terms of trade: This analysis included a variable representing growth rate of terms of trade. Terms of trade represents ratio of import prices to export prices. The variable terms of trade included in the regression thus represents a product of the terms of trade and openness ratio, that is, exports plus imports divided by GDP. This variable is taken to take in account of the effects of changes in international prices on incomes of domestic residents (Barro, 2003). The data is taken from UNCTAD handbook of statistics 200607, UNData, UN: Statistical Yearbook of various years and PENN World Table and the variable included is the average over each period.

vii. Inflation Rate: Inflation rate is included in the analysis to take in account of the macroeconomic instability. The inflation rate is calculated from consumer price index ${ }^{5}$. The variable inf included is averaged over each period and the data is taken from ILO- LABORSTA Labour Statistics Database and UN: Statistical Yearbook for various years.

The year dummies and the country dummies are same as considered in Model I.

\section{B. Regression Results and Interpretation}

Table 3 gives us the regression results for the growth rate of real per capita GDP. This regression includes 40 countries for the periods 1980-85, 1985-90, 199095, 1995-2000 and 2000-05. 
Table 3: Panel Regression for Growth Rate of Real Per Capita GDP, 5-Year Intervals from 1980 to 2005

\begin{tabular}{|c|c|c|c|c|}
\hline \multirow[t]{2}{*}{$\begin{array}{l}\text { Independent } \\
\text { Variables }\end{array}$} & \multicolumn{4}{|c|}{$\begin{array}{l}\text { Dependent Variables: Growth Rate of Real Per-Capita } \\
\text { GDP, 5-Year Intervals from } 1980 \text { to } 2005\end{array}$} \\
\hline & $I$ & II & III & $I V$ \\
\hline Log(Initial GDP) & $\begin{array}{l}-0.023 \\
(0.005,0.000)\end{array}$ & $\begin{array}{l}-0.022 \\
(0.005,0.000)\end{array}$ & $\begin{array}{l}-0.024 \\
(0.006,0.000)\end{array}$ & $\begin{array}{l}-0.020 \\
(0.005,0.000)\end{array}$ \\
\hline $\begin{array}{l}\text { Male upper-level schooling } \\
\text { (male-schooling) }\end{array}$ & $\begin{array}{l}0.000 \\
(0.003,0.908)\end{array}$ & $\begin{array}{l}-0.001 \\
(0.003,0.736)\end{array}$ & $\begin{array}{l}-0.002 \\
(0.003,0.632)\end{array}$ & $\begin{array}{l}0.004 \\
(0.003,0.167)\end{array}$ \\
\hline 1/(life expectancy at birth) & $\begin{array}{l}-1.240 \\
(1.217,0.314)\end{array}$ & $\begin{array}{l}-2.168 \\
(1.105,0.057)\end{array}$ & $\begin{array}{l}-2.904 \\
(1.255,0.026)\end{array}$ & $\begin{array}{l}-1.812 \\
(1.182,0.133)\end{array}$ \\
\hline $\begin{array}{l}\log (\text { total fertility rate) } \\
{[\log (\text { fert })]}\end{array}$ & $\begin{array}{l}-0.017 \\
(0.009,0.056)\end{array}$ & $\begin{array}{l}-0.008 \\
(0.008,0.322)\end{array}$ & $\begin{array}{l}-0.001 \\
(0.007,0.950)\end{array}$ & $\begin{array}{l}-0.017 \\
(0.009,0.051)\end{array}$ \\
\hline $\begin{array}{l}\text { Govt. consumption ratio } \\
\text { (Govt-Con) }\end{array}$ & $\begin{array}{l}-0.000 \\
(0.000,0.709)\end{array}$ & $\begin{array}{l}-0.000 \\
(0.000,0.601)\end{array}$ & $\begin{array}{l}-0.000 \\
(0.000,0.692)\end{array}$ & $\begin{array}{l}-0.000 \\
(0.000,0.968)\end{array}$ \\
\hline Conflict index & $\begin{array}{l}-0.000 \\
(0.000,0.674)\end{array}$ & $\begin{array}{l}-0.000 \\
(0.000,0.544)\end{array}$ & $\begin{array}{l}-0.000 \\
(0.000,0.606)\end{array}$ & $\begin{array}{l}0.000 \\
(0.000,0.587)\end{array}$ \\
\hline Democracy & $\begin{array}{l}-0.013 \\
(0.009,0.162)\end{array}$ & $\begin{array}{l}-0.016 \\
(0.009,0.076)\end{array}$ & $\begin{array}{l}-0.015 \\
(0.007,0.056)\end{array}$ & $\begin{array}{l}-0.012 \\
(0.009,0.207)\end{array}$ \\
\hline Democracy squared & $\begin{array}{l}0.009 \\
(0.005,0.075)\end{array}$ & $\begin{array}{l}0.009 \\
(0.005,0.080)\end{array}$ & $\begin{array}{l}0.010 \\
(0.005,0.039)\end{array}$ & $\begin{array}{l}0.009 \\
(0.005,098)\end{array}$ \\
\hline Openness ratio & $\begin{array}{l}0.000 \\
(0.000,0.675)\end{array}$ & $\begin{array}{l}0.000 \\
(0.000,0.348)\end{array}$ & $\begin{array}{l}0.000 \\
(0.000,0.245)\end{array}$ & $\begin{array}{l}0.000 \\
(0.000,0.933)\end{array}$ \\
\hline Terms of trade & $\begin{array}{l}-0.000 \\
(0.000,0.624)\end{array}$ & $\begin{array}{l}-0.000 \\
(0.000,0.658)\end{array}$ & $\begin{array}{l}-0.000 \\
(0.000,0.581)\end{array}$ & $\begin{array}{l}-0000 \\
(0.000,0.664)\end{array}$ \\
\hline Investment ratio (Invt) & $\begin{array}{l}0.001 \\
(0.000,0.013)\end{array}$ & $\begin{array}{l}0.001 \\
(0.000,0.023)\end{array}$ & $\begin{array}{l}0.001 \\
(0.000,0.028)\end{array}$ & $\begin{array}{l}0.001 \\
(0.000,016)\end{array}$ \\
\hline Inflation rate (Inf) & $\begin{array}{l}-0.000 \\
(0.000,0.000)\end{array}$ & $\begin{array}{l}-0.000 \\
(0.000,0.000)\end{array}$ & $\begin{array}{l}-0.000 \\
(0.000,0.000)\end{array}$ & $\begin{array}{l}-0.000 \\
(0.000,0.000)\end{array}$ \\
\hline Quality & $\begin{array}{l}0.010 \\
(0.005,0.037)\end{array}$ & $\begin{array}{l}0.008 \\
(0.004,0.057)\end{array}$ & $\begin{array}{l}0.005 \\
(0.004,0.260)\end{array}$ & \\
\hline n1 & $\begin{array}{l}0.002 \\
(0.009,0.787)\end{array}$ & $\begin{array}{l}0.001 \\
(0.007,0.919)\end{array}$ & $\begin{array}{l}-0.012 \\
(0.008,0.144)\end{array}$ & $\begin{array}{l}0.001 \\
(0.009,0.887)\end{array}$ \\
\hline $\mathrm{n} 2$ & & & $\begin{array}{l}-0.007 \\
(0.006,0.295)\end{array}$ & \\
\hline n3 & & $\begin{array}{l}-0.012 \\
(0.005,0.018)\end{array}$ & $\begin{array}{l}-0.031 \\
(0.009,0.002)\end{array}$ & \\
\hline n4 & & & $\begin{array}{l}-0.031 \\
(0.013,0.019)\end{array}$ & \\
\hline n5 & & & $\begin{array}{l}-0.020 \\
(0.010,0,044)\end{array}$ & \\
\hline n6 & $\begin{array}{l}-0.024 \\
(0.009,0.011)\end{array}$ & $\begin{array}{l}-0.030 \\
(0.008,0.001)\end{array}$ & $\begin{array}{l}-0.057 \\
(0.014,0.000)\end{array}$ & $\begin{array}{l}-0.020 \\
(0.009,0.041)\end{array}$ \\
\hline n7 & & & $\begin{array}{l}-0.009 \\
(0.006,0.145)\end{array}$ & \\
\hline y1 & $\begin{array}{l}-0.000 \\
(0.003,0.945)\end{array}$ & $\begin{array}{l}-0.002 \\
(0.003,0.502)\end{array}$ & $\begin{array}{l}-0.006 \\
(0.004,0.113)\end{array}$ & $\begin{array}{l}-0.001 \\
(0.003,0.723)\end{array}$ \\
\hline $\mathrm{y} 2$ & $\begin{array}{l}0.007 \\
(0.004,0.069)\end{array}$ & $\begin{array}{l}0.005 \\
(0.003,0.184)\end{array}$ & $\begin{array}{l}0.002 \\
(0.004,0.700)\end{array}$ & $\begin{array}{l}0.006 \\
(0.004,0.131)\end{array}$ \\
\hline y3 & $\begin{array}{l}0.002 \\
(0.004,0.632)\end{array}$ & $\begin{array}{l}0.001 \\
(0.003,0.868)\end{array}$ & $\begin{array}{l}-0.002 \\
(0.004,0.678)\end{array}$ & $\begin{array}{l}0.001 \\
(0.004,0.803)\end{array}$ \\
\hline y4 & $\begin{array}{l}0.007 \\
(0.004,0.063)\end{array}$ & $\begin{array}{l}0.007 \\
(0.004,0.070)\end{array}$ & $\begin{array}{l}0.006 \\
(0.004,0.141)\end{array}$ & $\begin{array}{l}0.007 \\
(0.004,0.084)\end{array}$ \\
\hline
\end{tabular}




\begin{tabular}{|l|l|l|l|l|}
\hline \multirow{2}{*}{$\begin{array}{l}\text { Independent } \\
\text { Variables }\end{array}$} & \multicolumn{4}{|c|}{ Dependent Variables: Growth Rate of Real Per-Capita } \\
\cline { 2 - 5 } & \multicolumn{1}{|c|}{$\boldsymbol{I}$} & \multicolumn{1}{c|}{$\boldsymbol{I I}$} & \multicolumn{1}{c|}{ III } & \multicolumn{1}{c|}{ IV } \\
\hline Constant & 0.243 & 0.246 & 0.285 & 0.212 \\
& $(0.052$, & $(0.050,0.000)$ & $(0.062,0.000)$ & $(0.048,0.000)$ \\
& $0.000)$ & & & \\
\hline No. of Observations & 200 & 200 & 200 & 200 \\
\hline $\mathrm{R}^{2}$ & 0.3561 & 0.3808 & 0.4044 & 0.3429 \\
\hline
\end{tabular}

NOTE: The observations in the parentheses represent robust standard errors and p-values respectively.

Column IV of Table 3 reports the regression results using most of the variables as used in Barro (2003). Quality is not included in this case. Here, it is seen that $\log ($ initial GDP), $\log ($ Fert), Invt, Inf and the regional dummy for Sub Saharan Africa $\left(n_{6}\right)$ appear to be statistically significant in explaining growth rate of countries. The variable democracy squared also appears to be marginally significant. In our sample of countries, male-schooling turns out to be statistically insignificant.

Next, the variable quality is included in the regression. Column I of Table 3 shows the results in this case. It is seen $\log$ (initial GDP), $\log$ (Fertility rate) and the regional dummy for Sub Saharan Africa $\left(n_{6}\right)$ are statistically significant with the expected correct signs, predicting the same effects as in Model I. Only here, it can be said that the rate of convergence is about 2.3 percent per year.

It is also seen here that the democracy variable is insignificant but the square term is marginally significant. However, it is seen that in other cases the democracy variable is also marginally significant. This may indicate that political and civil liberties fall, as the value of the variable Democracy increases. So a negative coefficient implies that as freedom increases, it poses a positive impact on growth rate of economies. From the square term, it can be said that though growth rate increases with increase in political freedom and civil liberties, this increase occurs at a diminishing rate. Thus, democratization increases growth for not so democratic countries but retards this pace is slowed for countries with considerable amount of democracy (Barro, 2003).

Invt, here, turns out to be statistically significant, with a positive sign. So, it can be said that greater investment leads to high growth rates. Inflation rate (inf) also gives a statistically significant and a negative impact on economic growth (though the impact is very weak). The significance of some of the year dummies may indicate fall in growth rate of countries over the years.

The educational quality variable (quality) included in this analysis turns out to be statistically significant with a positive sign, implying that importance give to 
quality of education can have a significant positive impact on growth rates of economies.

In Column II of Table 3, the dummy for Latin America and the Caribbean $\left(n_{3}\right)$ is included. The results are similar as in Column I, only $\log (f e r t)$ remains no longer significant. Democracy becomes marginally significant. $1 /$ (life expectancy at birth) becomes statistically significant in this cases, with a high value estimated coefficient (negative), indicating improvement of health predicts higher growth.

In Column III, all the regional dummies are included. The results are similar as Column II. However, in this case, both male upper-level schooling and quality turns out to be statistically insignificant.

Thus, it is seen that $\log ($ initial GDP), Investment ratio, Inflation rate and Fertility rate appear as important variables in explaining growth rate of countries. It is also seen quality of education affects growth rate positively. The variable male upperlevel schooling is insignificant in most cases, even when the quality variable is dropped. However, when both are included, only the quality variable turns out to be statistically significant, indicating the importance of quality of education (except in one specification, where both the variables are insignificant).

\section{Summary and Conclusion}

Human capital should be considered along with physical capital to determine whether differences in capital are important to differences in income across nations. Many growth regressions including human capital in the set of regressors have appeared following early works of Barro and others (e.g. Barro (1991)). Generally primary or secondary school enrolment rates or average years of educational attainment were used to represent human capital in these cases [e.g. Barro (1991), Mankiw, Romer and Weil (1992), Barro and Lee (1993), Barro (2000)]. But the problem of these measures is that they measure quantity of human capital, not the quality. This paper tries to explore whether quality of education have any independent effect on economic growth.

There are some studies which measure quality of human capital (Hanushek and Kimko, 2000; Barro and Lee, 2001a). They use academic achievement, that is, test scores in some common examination to represent quality of education. But the problem with this measure is that test scores come from different sources, are based 
on different time periods, different sample sizes. Students appearing for the exams study in different curricula and are of different ages. This hampers comparison across countries. Moreover, these tests are not conducted in all countries.

Again, reading proficiency is significantly related to growth rates of real per capita GDP [Barro and Lee (2001a)]. Reading proficiency of the working population cannot be captured by quantity of education as measured by literacy rates, enrolment rates or years of schooling but depends on the quality of education of the workforce. This paper considers the per capita circulation of newspapers in an economy as an indicator of the level of reading proficiency of the working population. Circulation of newspapers can represent major portion of the population since its access and distribution is present in most countries and it can also represent the ability and inclination to read.

This paper investigates the effects of the quality of education on the reading proficiency of the present working population, measured by per capita circulation of newspapers, in terms of the influence of family factors and school resources during schooling of the present work force. This study is based on a panel data set including 40 countries. The data of the circulation of newspapers relates to the years 1980 , 1985, 1990, 1995 and 1998 and the corresponding years representing the family factors and school resources during schooling period of the present work force are 1960, 1965, 1970, 1975 and 1980 respectively.

Apart from the present control variables it is seen that, parents' education has a significant effect on the reading proficiency of the workforce. It is also seen that government's initiative to impart education, provide educational facilities and develop educational infrastructure is important for increasing reading proficiency of the workforce. Even if private initiative is important, if it is backed up by government's initiative, the effect is increased.

So, it can be said that reading proficiency of the workforce (or quality of literacy of the present work-force) might be dependent on the importance given to quality education during their schooling to a certain extent.

On the basis of the above analysis, a measure of the quality of education in terms of its effect on the per capita circulation of newspapers is framed and this is included in the analysis of finding the determinant of growth rate of economies. This analysis is done for a maximum of 40 countries, for the time period 1980 to 2005. Here, it is seen that some of the important variables in explaining growth rate of 
economies are initial GDP, fertility rate, investment ratio, macroeconomic and political stability.

Most importantly, except in the case of one specification where both quantity and quality of education are both not significant, the quality of education is seen to significantly influencing growth rates. The variables representing quantity of education appears to be statistically insignificant in all cases, even when quality of education is not included in the analysis. However, quality turns out to be positively significant even in presence of the quantity variables. This may imply that quantity of education alone cannot influence growth rate of economies. However, quality of education can have a positive impact on growth rates on nations. 


\section{Appendix I: Countries and Regions}

\begin{tabular}{|c|c|}
\hline Regions & Countries Included \\
\hline East Asia and Pacific (n1) & Japan, Malaysia, Singapore and Thailand \\
\hline Europe (n2) & $\begin{array}{l}\text { Austria, Belgium, Denmark, Finland, } \\
\text { France, Hungary, Ireland, Italy, } \\
\text { Netherlands, Norway, Portugal, Sweden, } \\
\text { Switzerland and United Kingdom }\end{array}$ \\
\hline Latin America and the Caribbean (n3) & $\begin{array}{lll}\text { Argentina, Columbia, } & \text { Costa } & \text { Rica, } \\
\text { Dominican Republic, Ecuador, El } \\
\text { Salvador and Peru }\end{array}$ \\
\hline Middle East and North Africa (n4) & Algeria and Egypt \\
\hline South Asia (n5) & India and Sri Lanka \\
\hline Sub Saharan Africa (n6) & $\begin{array}{l}\text { Cameroon, Republic of Congo, Gambia, } \\
\text { Ghana, Kenya, Lesotho and Niger }\end{array}$ \\
\hline Oceania (n7) & Australia and New Zealand \\
\hline North America (n8) & Canada and United States of America \\
\hline
\end{tabular}




\section{Appendix II: Endnotes}

${ }^{1}$ Press freedom index is an index formed by Freedom House. This index ranges from 0 to 100 and it is formed taking in consideration some causes that influence media content like laws and regulations, political pressures and violence, economic pressures and controls and actual press-freedom violations. Marks in the range 0 to 30 represents press free group, 31 to 60 represents partially free press group and 61 to 100 represents not-free press group. In the present case, the number 0 is assigned for the free press group, 1 for partially free press group, and 2 for the not free press group.

${ }^{2}$ Average growth rate of real GDP per capita: $r=\left(Y_{t} / Y_{0}\right)^{(1 / t)}-1$

where, $Y_{0}$ is the initial GDP, $Y_{t}$ is the GDP after time $t, t$ is the time period considered.

${ }^{3}$ Measure of free trade openness is given by

Openness $=[0.528-0.026 \log ($ AREA $)-0.095 \log (D I S T)]$

where, $A R E A$ is size of land, million squares $\mathrm{km}$ and DIST is the average distance to capitals of world 20 major exporters, weighted by values of bilateral imports in 1985. The distance to major world exporters is used in each country as a proxy for natural trade barriers, such as transportation and other transaction costs. The source of these data is Lee (1993) and the data set is obtained from Barro and Lee (1994)

Average tariff rates on capital imports and intermediaries are here calculated on the basis of import tariff rates on chemicals and machinery and transport equipment and then these are weighted by their share in imports.

The final variable used in the analysis is [openness $* \log (1+$ tariff rate $)]$ based on Barro and Lee (1994) and this measures the distortions due to tariffs.

${ }^{4}$ The variable democracy used in our analysis uses the data of The Freedom of the World Survey. The Freedom in the World survey gives an annual evaluation of the state of global freedom as experienced by individuals in terms of political rights and civil liberties. Political rights permit people to participate freely in the political process, including the right to vote freely for distinct alternatives in legitimate elections, compete for public office, join political parties and organizations, and elect representatives who have a decisive impact on public policies and are accountable to 
the electorate. Civil liberties allow for the freedoms of expression and belief, associational and organizational rights, rule of law, and personal autonomy without interference from the state. The ratings process is based on 10 political rights questions and 15 civil liberties questions. The total number of points awarded to the political rights and civil liberties questions determine the political rights and civil liberties ratings. Ratings are given from 1 to 7 , with 1 representing the highest and 7 the lowest level of freedom. Each pair of political rights and civil liberties ratings is averaged to determine an overall status of Free (average ratings 1.0 to 2.5), Partly Free (average ratings 3.0 to 5.0) or Not Free (average ratings 5.5 to 7.0).

In our case, the scores given by Freedom House are averaged over each period and ranks are given to each for each period on the basis of the average scores. In the present case, the number 0 is assigned for the free group, 1 for partially free group, and 2 for the not free group.

${ }^{5}$ The formula used in calculation of inflation rate between two time points is: $[(B-A) / A]^{*} 100$

where, $A$ is the consumer price index at the beginning of the time period and $B$ is the consumer price index at the end of the time period. 
Appendix III: Trends in Circulation of Newspapers by Region

\begin{tabular}{|c|c|c|c|}
\hline Regions & Year & $\begin{array}{c}\text { Total Population (in } \\
\text { thousands) }\end{array}$ & $\begin{array}{c}\text { Circulation } \\
\text { of } \\
\text { newspapers } \\
\text { (per } 1000 \\
\text { inhabitants) }\end{array}$ \\
\hline \multirow{5}{*}{$\begin{array}{l}\text { East } \text { Asia and Pacific } \\
\text { ( } 4 \text { countries) }\end{array}$} & 1980 & 45002.83 & 242.3 \\
\hline & 1985 & 47621.18 & 255.5 \\
\hline & 1990 & 49826.85 & 272.5 \\
\hline & 1995 & 51864.46 & 265.0 \\
\hline & 1998 & 53061.01 & 290.3 \\
\hline \multirow{5}{*}{$\begin{array}{l}\text { Europe } \\
\text { (14 countries) }\end{array}$} & 1980 & 17849.66 & 314.2 \\
\hline & 1985 & 18071.28 & 328.9 \\
\hline & 1990 & 18320.50 & 328.6 \\
\hline & 1995 & 18664.96 & 287.4 \\
\hline & 1998 & 18836.88 & 276.2 \\
\hline \multirow{5}{*}{$\begin{array}{l}\text { Latin America and the Caribbean } \\
\text { (7countries) }\end{array}$} & 1980 & 13247.23 & 79.1 \\
\hline & 1985 & 14675.09 & 78.9 \\
\hline & 1990 & 16198.54 & 75.6 \\
\hline & 1995 & 17774.43 & 69.3 \\
\hline & 1998 & 18715.33 & 38.2 \\
\hline \multirow{5}{*}{$\begin{array}{l}\text { Middle East and North Africa } \\
\text { ( } 2 \text { countries) }\end{array}$} & 1980 & 30747.92 & 31.5 \\
\hline & 1985 & 36117.32 & 37.0 \\
\hline & 1990 & 41017.84 & 47.0 \\
\hline & 1995 & 45842.84 & 44.5 \\
\hline & 1998 & 48845.33 & 31.5 \\
\hline \multirow{5}{*}{$\begin{array}{l}\text { South Asia } \\
\text { ( } 2 \text { countries) }\end{array}$} & 1980 & 350964.73 & 25.5 \\
\hline & 1985 & 389202.37 & 25.0 \\
\hline & 1990 & 429424.00 & 31.5 \\
\hline & 1995 & 470190.56 & 38.6 \\
\hline & 1998 & 494817.54 & 44.4 \\
\hline \multirow{5}{*}{$\begin{array}{l}\text { Sub Saharan Africa } \\
\text { ( } 7 \text { countries) }\end{array}$} & 1980 & 6533.51 & 14.8 \\
\hline & 1985 & 7781.00 & 13.6 \\
\hline & 1990 & 9077.66 & 8.0 \\
\hline & 1995 & 10382.31 & 7.2 \\
\hline & 1998 & 11092.46 & 6.6 \\
\hline \multirow{5}{*}{$\begin{array}{l}\text { Oceania } \\
\text { ( } 2 \text { countries) }\end{array}$} & 1980 & 8875.61 & 328.5 \\
\hline & 1985 & 9458.11 & 303.0 \\
\hline & 1990 & 10142.03 & 288.0 \\
\hline & 1995 & 10799.24 & 262.0 \\
\hline & 1998 & 11186.23 & 188.5 \\
\hline \multirow{5}{*}{$\begin{array}{l}\text { North America } \\
\text { ( } 2 \text { countries) }\end{array}$} & 1980 & 127716.74 & 245.5 \\
\hline & 1985 & 134449.10 & 239.0 \\
\hline & 1990 & 141619.93 & 229.0 \\
\hline & 1995 & 149452.45 & 191.5 \\
\hline & 1998 & 154242.52 & 183.5 \\
\hline
\end{tabular}

NOTE: Data for Population is taken from Penn World Table (taken from World Bank World Development Indicators, 2001) 
Appendix IV: Trends in Quality of Education by Region

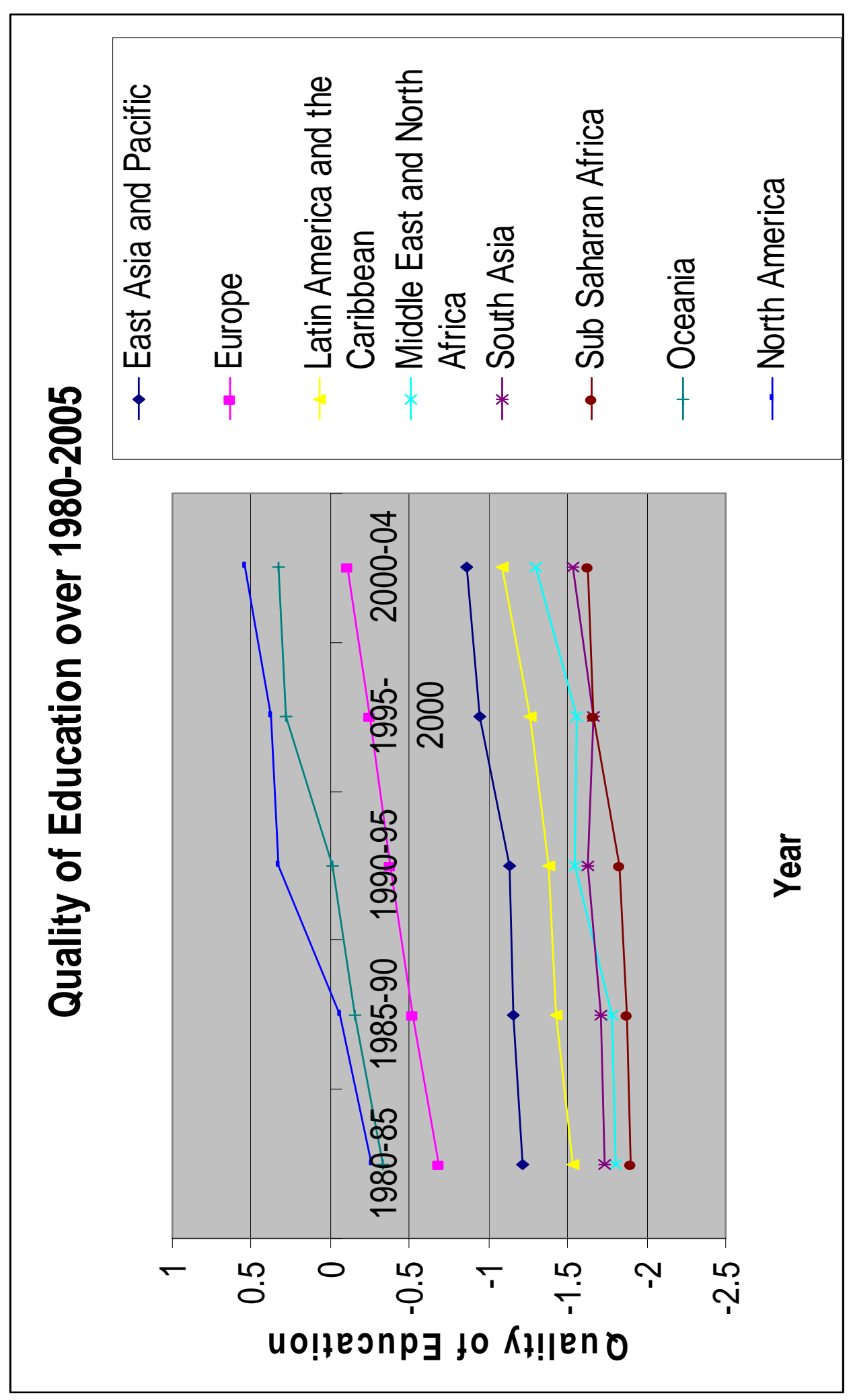




\section{REFERENCES:}

Angrist, Joshua D., and Lavy, Victor, 1999. Using Maimonides’ Rule to Estimate the Effect of Class Size on Children's Academic Achievement. Quarterly Journal of Economics, Vol. 114 (May), p. 533-575.

Arrow, Kenneth J., 1962. The Economic Implications of Learning by Doing. The Review of Economic Studies, Vol. 29, No. 3, p. 155-173.

Banks, A.S., 1999. Cross-National Time Series Data Archive. Center for Social Analysis, State University of New York at Binghampton, September 1999.

Barro, R. J., 1991. Economic growth in a cross-section of countries. Quarterly Journal of Economics, Vol. 106, No. 2, p. 407-443.

Barro, R. J., 1992. Human Capital and Economic Growth. Federal Reserve Bank of Kansas City- Journal Proceedings, p. 1999-230.

Barro, R. J., 2000. Education and economic growth. Paper presented at the international symposium on the contribution of human and social capital to sustained economic growth and well-being, organised by the OECD and HRDC, Quebec City, Canada, 19-21 March 2000.

Barro, R. J., 2003. Determinants of Economic Growth in a Panel of Countries. Annals of Economics and Finance, Vol. 4, p. 231-274.

Barro, R. J. and Lee, Jong-Wha, 1993. International comparisons ofeducational attainment. Journal of Monetary Economics, Vol. 32, No. 3, p. 363-394.

Barro, R. J. and Lee, Jong-Wha, 1994. Data Set for a Panel of 138 Countries. Available at:http://www.economics.harvard.edu/faculty/barro/INDEX.HTM 
Barro, R. J. and Lee, Jong-Wha, 1996. International measures of schooling years and schooling quality. American Economic Review, Vol. 86, No. 2, p. 218-223 (Papers and proceedings).

Barro, R. J. and Lee, Jong-Wha, 2001(a). Schooling Quality in a Cross-Section of Countries. Economica, Vol. 68, No. 272, p. 465-488(24).

Barro, R. J. and Lee, Jong-Wha, 2001(b). International data on educational attainment: Updates and implications. Oxford Economic Papers, p. 541-563.

Barro, R. J. and Sala-I-Martin, X., 1995. Economic Growth. New York: McGraw Hill.

Card, David and Krueger, Alan B., 1992. Does School Quality Matter? Returns to Education and the Characteristics of Public Schools in the United States. Journal of Political Economy, Vol. 100, No. 1, p. 1-40.

Drèze, J. and Sen, A., 2002. India: Development and Participation. Oxford: Oxford University Press.

Gemmell, N., 1996. Evaluating the impacts of human capital stocks and accumulation on economic growth: some new evidence. Oxford Bulletin of Economics and Statistics, Vol. 58, No. 1, p. 9-28.

Hanushek, E. A. and Kimko, D., 2000. Schooling, labour force quality and the growth of nations. American Economic Review, Vol. 90, No. 5, p. 1184-1208.

Heston, Alan, Robert Summers and Bettina Aten, 2006. Penn World Table Version 6.2. Center for International Comparisons of Production, Income and Prices at the University of Pennsylvania, September 2006.

Heyneman, Stephen and Loxley, William, 1983. The Effect of Primary School Quality on Academic Achievement across Twenty-nine High and Low-Income Countries. American Journal of Sociology, Vol. 88, No. 6, p. 1162-1194. 
Jones, Garett and Schneider, W. Joel, 2006. Intelligence, Human Capital, and Economic Growth: A Bayesian Averaging of Classical Estimates (BACE) Approach. Journal of Economic Growth, Vol. 11, No. 1, p. 71-93.

Krueger, Alan B., 1999. Experimental Estimates of Education Production Functions. Quarterly Journal of Economics, Vol. CXIV (May), p. 497-532.

Learning Achievement of Class-V Children: A Mid Term National Survey- Executive Summary. MAS 2008. National Council of Educational Research \& Training. (http://www.ncert.nic.in/html/pdf/achivement_surveys/Achievement_survey.pdf).

Lee, Jong-Wha, 1993. International Trade, Distortions, and Long-Run Economic Growth. Staff Papers - International Monetary Fund, Vol. 40, No. 2, p. 299-328.

Lucas, R. E., 1988. On the mechanics of economic development. Journal of Monetary Economics, Vol. 22, No. 1, p. 3-42.

Mankiw, N. G., Romer, D. and Weil, D. N., 1992. A contribution to the empirics of economic growth. Quarterly Journal of Economics, Vol. 107, No. 2, p. 407-437.

Romer, P. M., 1986. Increasing returns and long-run growth. Journal of Political Economy, Vol. 94, No. 5, p. 1002-1037.

Rebelo, Sergio, 1991. Long-Run Policy Analysis and Long-Run Growth. The Journal of Political Economy, Vol. 99, No. 3, p. 500-521.

Sheshinski, Eytan, 1967. Tests of the "Learning by Doing" Hypothesis. The Review of Economics and Statistics, Vol. 49, No. 4. p. 568-578.

Solow, Robert M., 1956. A Contribution to the Theory of Economic Growth. Quarterly Journal of Economics, Vol. 70, No. 1 (February), p. 65-94.

Statistical Yearbook 1987, 1993, 1997, 1999, 2001, 2004, 2006 and 2008. Department of Economic and Social Affairs, Statistics Division, United Nations, New York. 
Summers, Anita and Wolfe, Barbara, 1977. Do Schools Make a Difference? American Economic Review, Vol. 67, No. 4, p. 639-652.

UNCTAD Handbook of Statistics: 2006-07. United Nations Conference on Trade and Development, United Nations.

UNESCO: The Statistical Yearbook, 1970, 1973, 1977, 1978-79 and 1980. The UNESCO Press.

UNICEF, 2000. Defining Quality in Education. New York, UNICEF.

Uzawa, Hirofumi., 1965. Optimum Technical Change in an Aggregative Model of Economic Growth. International Economic Review, Vol. 6, No. 1, p. 18-31.

\section{Websites:}

Freedom House: http://www.freedomhouse.org

HNPStats - the World Bank's comprehensive database of Health, Nutrition and Population (HNP) statistics:

http://web.worldbank.org/WBSITE/EXTERNAL/TOPICS/EXTHEALTHNUTRITIO

NANDPOPULATION/EXTDATASTATISTICSHNP/EXTHNPSTATS/0,,menuPK:3

237172 pagePK:64168427 piPK:64168435 theSitePK:3237118,00.html

ILO: LABORSTA Labour Statistics Database: http://laborsta.ilo.org

Penn World Table: http://pwt.econ.upenn.edu

Stockholm International Peace Research Institute: http://www.sipri.org

UNCTAD: http://www.unctad.org

UNData: http://data.un.org

UNESCO Institute of Statistics: http://www.uis.unesco.org

United Nations Statistical division: http://unstats.un.org

World Bank, World Development Indicators 2001: www.worldbank.org 